\title{
Effect of cerebrolysin on dopaminergic neurodegeneration of rat with oxidative stress induced by 3-nitropropionic acid
}

\author{
DAVID CALDERÓN GUZMÁN ${ }^{1}$ \\ NORMA OSNAYA BRIZUELA ${ }^{1}$ \\ MARIBEL ORTÍZ HERRERA ${ }^{2}$ \\ ERNESTINA HERNÁNDEZ GARCÍA ${ }^{3}$ \\ GERARDO BARRAGÁN MEJÍA ${ }^{1}$ \\ HUGO JUÁREZ OLGUÍN ${ }^{3 *}$ \\ ARMANDO VALENZUELA PERAZA ${ }^{1}$ \\ JONAS ATTILUS ${ }^{1}$ \\ NORMA LABRA RUÍZ \\ ${ }^{1}$ Laboratorio de Neurociencias \\ Instituto Nacional de Pediatría (INP) \\ México City, México \\ ${ }^{2}$ Laboratorio de Bacteriología Experimental \\ INP, México City, México \\ ${ }^{3}$ Laboratorio de Farmacología, INP \\ México City, México
}

Accepted March 8, 2016 Published online May 16, 2016

\begin{abstract}
The study tested the hypothesis that cerebrolysin protects the brain from free radicals in rats treated with 3-nitropropionic acid (3-NPA). To address this hypothesis, the levels of dopamine (DA) and some oxidative stress biomarkers were measured after administration of 3-NPA. Young male Fischer rats were treated for three days with cerebrolysin, 3-NPA or both substances. Their brains were extracted, and DA, lipid peroxidation (LP), glutathione (GSH), calcium, and $\mathrm{H}_{2} \mathrm{O}_{2}$ were measured using validated methods. In the cortex, hemispheres and cerebellum/medulla oblongata of the group treated with cerebrolysin and 3-NPA, the levels of DA and LP decreased. In addition, calcium and $\mathrm{H}_{2} \mathrm{O}_{2}$ levels decreased in the hemispheres of the same group, while GSH increased in cortex. The increased dopamine metabolism due to the administration of cerebrolysin led to increased formation of radical species and oxidative stress, especially when free radicals were generated by 3-NPA.
\end{abstract}

Keywords: cerebrolysin, dopamine, 3-nitropropionic acid, oxidative stress

Studies of neurological disorders suggest that excitotoxicity induces a huge increase in intracellular $\mathrm{Ca}^{2+}$ concentrations and an increase in the production of free radicals via lethal pathways (1). This damage is the primary event in 3-nitropropionic acid (3-NPA) toxicity, which induces neurodegeneration in female Wistar rats, and its systemic administration to rats is used as an important model of Huntington's disease (2). Cerebrolysin is a drug that consists of small brain-derived peptides, which are similar or identical to those produced endogenously. Its content of $25 \%$ of low-molecule peptides allows it to partially cross the blood-brain barrier (3). Cerebrolysin improves synaptic plasticity and behavioral performance and has been successfully studied in animal models, in which it was proved to substantially decrease oxidative stress (4), which particularly affects the central nervous system. However, its mechanism of action is not completely clear. The above findings suggest that cerebrolysin may have therapeutic efficacy. As free radicals are known to damage

\footnotetext{
*Correspondence; e-mail: juarezol@yahoo.com
} 
cell components, mainly plasma membrane lipids (5), the central nervous system is particularly susceptible to their effects.

Based on the above, the purpose of the present study is to compare the protective effect of cerebrolysin alone with that of cerebrolysin combined with 3-nitropropionic acid on the levels of dopamine (DA) and of selected oxidative stress biomarkers in important brain regions in young rats.

\section{EXPERIMENTAL}

Animal management and care were conducted in accordance with the international guidelines on animal care and Mexican Guidelines ZOO-062. Approval of the institutional ethical committee was obtained.

Twenty-four young male Fischer rats ( $80 \mathrm{~g}$, 45 days old, were deployed for the study and were procured from the certified Bioterium of the Metropolitan University of Mexico City, Mexico, with a balanced food (Rodent diet 5001) and drinking water ad libitum. The animals were divided into 4 groups $(n=6)$ and were treated as follows: control group $(\mathrm{NaCl}$ $0.9 \%)$, cerebrolysin group ( $2.5 \mathrm{~g} \mathrm{~kg}^{-1}$ b.m.), cerebrolysin $\left(2.5 \mathrm{~g} \mathrm{~kg}^{-1}\right.$ b.m. $)+3$-nitropropionic acid group (20 $\mathrm{mg} \mathrm{kg}^{-1}$ b.m.) and 3-nitropropionic acid group (20 mg kg-1 b.m.). All substances were administered intraperitoneally every 24 hours for 3 consecutive days. Thirty minutes after the final drug administration, the animals were sacrificed using a guillotine and their brains were immersed in saline solution $(\mathrm{NaCl} 0.9 \%)$ at $4{ }^{\circ} \mathrm{C}$.

Blood was obtained immediately after sacrifice and evaluated for glucose and hemoglobin levels. Brain region dissections were carried out for the cortex, hemispheres, and cerebellum combined with the medulla oblongata. Dissected brain regions were stored in 5 volumes of $0.05 \mathrm{~mol} \mathrm{~L}^{-1}$ Tris- $\mathrm{HCl}, \mathrm{pH} 7.4$, and evaluated for ATPase, lipid peroxidation and $\mathrm{H}_{2} \mathrm{O}_{2}$ levels. An aliquot from each region was homogenized in $0.1 \mathrm{~mol} \mathrm{~L}^{-1}$ perchloric acid (50:50, V/V) to evaluate the concentrations of reduced glutathione (GSH), dopamine, and calcium.

Measurement of blood glucose was performed in all groups of animals at the moment of sacrifice in non-anticoagulant blood using Accu-Chek Active (Roche Mannheim, Germany) glucose meters (6).

The DA levels were quantified in the supernatant of tissue homogenized in $\mathrm{HClO}_{4}$ after centrifugation at 9,000 rpm for $10 \mathrm{~min}$ in a microcentrifuge (Mikro 12-42, Hettich Zentrifugen, Germany) using the method reported by Calderon et al. (7).

GSH levels were measured in the perchloric acid supernatant of the homogenized tissue, obtained after centrifuging at 9,000 rpm for 5 min using a method modified after Hissin and Hilf (8).

TBARS determination was performed using modified method of Gutteridge and Halliwell (5). To measure calcium, the supernatant from brain homogenates of all animal groups was evaluated using the Ca-Color Arsenazo III AA direct colorimetric method produced by Wiener Laboratory (Rosario, Argentina).

The ATPase activity was assayed according to the method proposed by CalderónGuzmán et al. (9). Supernatant absorbance was quantified at $660 \mathrm{~nm}$ (Helios- $\alpha$ UNICAM spectrophotometer, UK).

Determination of $\mathrm{H}_{2} \mathrm{O}_{2}$ was performed using a modified method from Asru (10). 


\section{Statistics}

Kruskal-Wallis and ANOVA tests were used with their corresponding contrasts and previous variance homogeneity comparison. Statistical significance was defined at $p<0.05$. JMP Statistical Discovery software of the SAS version 8.0.0 was used.

\section{RESULTS AND DISCUSSION}

Hemoglobin level showed a non-significant decrease in animal groups treated with cerebrolysin plus 3-NPA or with 3-NPA alone but these groups showed a statistically significant increase in the glucose level $(p<0.05)$.

Dopamine levels in brain regions of young rats treated with cerebrolysin and 3-nitropropionic acid decreased significantly $(p<0.03)$ in the cortex (Table II), hemispheres (Table III) and cerebellum/medulla oblongata (Table IV) compared to the control or cerebrolysin group.

In animals treated with cerebrolysin alone or cerebrolysin plus 3-NPA, lipid peroxidation in the cortex decreased significantly $(p<0.02$, Table II) compared to the control. In animals treated with cerebrolysin and 3-NPA, calcium and $\mathrm{H}_{2} \mathrm{O}_{2}$ levels decreased significantly $(p<0.001)$ in hemisphere regions (Table III) compared with to the control group.

The GSH concentration increased in cortex regions in animals treated with cerebrolysin plus 3-NPA because of the production of reactive oxygen species is the primary event in 3-NPA toxicity (11). ATPase activity, which is dependent on calcium and magnesium, increased in the cortex and hemisphere regions of the animals that received cerebrolysin alone or in combination with 3-NPA, whereas it decreased in animals treated with 3-NPA alone. Increased $\mathrm{Ca}^{2+}, \mathrm{Mg}^{2+}-$ ATPase activity protects against substances that induce brain injury by inhibiting free radical production, regulating calcium-dependent processes, and supporting the antioxidant redox system.

DA signaling and distribution are primarily modulated by the DA transporter (DAT) and the vesicular monoamine transporter (VMAT)-2, which transport DA into presynaptic terminals and synaptic vesicles. These transporters are regulated by complex processes

Table I. Glucose and hemoglobin in the blood of young rats treated with cerebrolysin and 3-nitropropionic acid

\begin{tabular}{lcc}
\hline Group & $\begin{array}{c}\text { Glucose } \\
(\mathrm{mg} \text { per } 100 \mathrm{~mL})\end{array}$ & $\begin{array}{c}\text { Hemoglobin } \\
(\mathrm{g} \text { per 100 mL) }\end{array}$ \\
\hline Control $(\mathrm{NaCl} 0.9 \%)$ & $126.3 \pm 2.2^{\mathrm{a}}$ & $22.2 \pm 4.7$ \\
Cerebrolysin & $124.0 \pm 4.7^{\mathrm{b}}$ & $20.6 \pm 3.6$ \\
Cerebrolysin + 3-NPA & $149.3 \pm 7.8^{\mathrm{a}, \mathrm{b}}$ & $17.2 \pm 4.2$ \\
3-NPA & $146.00 \pm 3.0^{\mathrm{a}, \mathrm{b}}$ & $26.14 \pm 3.1$ \\
\hline
\end{tabular}

Applied doses: cerebrolysin (2.5 $\left.\mathrm{g} \mathrm{kg}^{-1}\right)$, 3-nitropropionic acid (3-NPA) (20 mg kg-1).

Mean value \pm SD, $n=6$.

a,b Statistically significant differences at $p<0.05$. 
D. C. Guzmán et al.: Effect of cerebrolysin on dopaminergic neurodegeneration of rat with oxidative stress induced by 3-nitropropionic acid, Acta Pharm. 66 (2016) 443-448.

Table II. Dopamine levels and biomarkers of oxidative stress in the cortex regions of young rats treated with cerebrolysin and 3-NPA

\begin{tabular}{|c|c|c|c|c|c|c|}
\hline Group & $\begin{array}{c}\text { DA } \\
\left.(\mu \mathrm{mol} \mathrm{g})^{-1}\right)^{a}\end{array}$ & 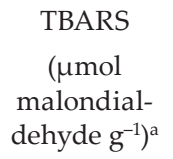 & $\begin{array}{l}\text { Calcium } \\
\text { (mg per } \\
100 \mathrm{~mL} \text { ) }\end{array}$ & $\begin{array}{c}\mathrm{H}_{2} \mathrm{O}_{2} \\
\left.(\mu \mathrm{mol} \mathrm{g})^{-1}\right)^{\mathrm{a}}\end{array}$ & $\begin{array}{c}\text { GSH } \\
\left(\mathrm{nmol} \mathrm{g}^{-1}\right)^{\mathrm{a}}\end{array}$ & $\begin{array}{c}\text { ATPase } \\
(\mu \mathrm{mol} \mathrm{Pi} \\
\left.\mathrm{g}^{-1} \mathrm{~min}^{-1}\right)^{\mathrm{a}}\end{array}$ \\
\hline Control & $2.20 \pm 0.93^{b}$ & $9.58 \pm 1.6^{\mathrm{b}}$ & $3.98 \pm 0.13$ & $0.12 \pm 0.03$ & $362.3 \pm 98^{b}$ & $161.7 \pm 54.0^{b}$ \\
\hline Cerebrolysin & $3.36 \pm 0.38^{b, c}$ & $7.84 \pm 1.0^{\mathrm{b}}$ & $4.09 \pm 0.41$ & $0.14 \pm 0.02$ & $332.9 \pm 128^{c}$ & $235.2 \pm 75.5^{\mathrm{b}, \mathrm{c}}$ \\
\hline $\begin{array}{l}\text { Cerebrolysin } \\
+3-\mathrm{NPA}\end{array}$ & $2.43 \pm 0.51^{\mathrm{c}}$ & $7.99 \pm 1.2^{b}$ & $4.25 \pm 0.30$ & $0.13 \pm 0.03$ & $441.05 \pm 74^{\mathrm{b}, \mathrm{c}, \mathrm{d}}$ & $244.1 \pm 35.9^{\mathrm{b}, \mathrm{d}}$ \\
\hline 3-NPA & $2.65 \pm 0.47^{\mathrm{b}, \mathrm{c}}$ & $8.05 \pm 0.7^{b}$ & $4.30 \pm 1.42$ & $0.08 \pm 0.02$ & $214.47 \pm 74^{\mathrm{b}, \mathrm{c}, \mathrm{d}}$ & $95.9 \pm 53.7^{b, c, d}$ \\
\hline
\end{tabular}

DA - dopamine, TBARS - thiobarbituric acid reactive substances, GSH - glutathione, 3-NPA - 3-nitropropionic acid Applied doses: cerebrolysin $\left(2.5 \mathrm{~g} \mathrm{~kg}^{-1}\right)$, 3-nitropropionic acid (3-NPA) (20 mg kg-1).

Mean value $\pm \mathrm{SD}, n=6$.

${ }^{a}$ Wet mass (tissue) basis.

b,c,d Statistically significant differences at $p<0.05$ within a parameter.

such as phosphorylation and protein-protein interactions. Thus, the peptide-containing drug cerebrolysin may act in this complex process (12) offering a therapeutic treatment of DA-related disorders.

Since dopamine levels increased in the cortex and hemisphere regions of animals that received cerebrolysin alone, it may be assumed that cerebrolysin is a novel dopamine agonist. The decrease of lipid peroxidation in the cortex regions of animals that received cere-

Table III. Dopamine levels and biomarkers of oxidative stress in hemispheres regions of young rats treated with cerebrolysin and 3-nitropropionic acid

\begin{tabular}{|c|c|c|c|c|c|c|}
\hline Group & $\begin{array}{c}\text { DA } \\
\left.(\mu \mathrm{mol} \mathrm{g})^{-1}\right)^{a}\end{array}$ & 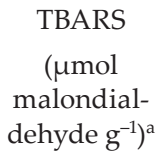 & $\begin{array}{l}\text { Calcium } \\
\text { (mg per } \\
100 \mathrm{~mL} \text { ) }\end{array}$ & $\begin{array}{c}\mathrm{H}_{2} \mathrm{O}_{2} \\
\left.(\mu \mathrm{mol} \mathrm{g})^{-1}\right)^{a}\end{array}$ & $\begin{array}{c}\text { GSH } \\
\left(\mathrm{nmol} \mathrm{g}^{-1}\right)^{\mathrm{a}}\end{array}$ & $\begin{array}{c}\text { ATPase } \\
(\mu \mathrm{mol} \mathrm{Pi} \\
\left.\mathrm{g}^{-1} \mathrm{~min}^{-1}\right)^{\mathrm{a}}\end{array}$ \\
\hline Control & $3.34 \pm 0.85$ & $11.8 \pm 0.9$ & $4.13 \pm 0.14^{b}$ & $0.20 \pm 0.02^{b}$ & $419.8 \pm 124$ & $253.5 \pm 104^{b}$ \\
\hline Cerebrolysin & $4.27 \pm 1.08^{b}$ & $13.05 \pm 1.9$ & $4.06 \pm 0.16^{c}$ & $0.19 \pm 0.02^{c}$ & $369.0 \pm 126$ & $603.8 \pm 193^{b, c}$ \\
\hline $\begin{array}{l}\text { Cerebrolysin } \\
+3-\mathrm{NPA}\end{array}$ & $3.29 \pm 0.86^{b}$ & $12.04 \pm 2.0$ & $3.79 \pm 0.07^{\mathrm{b}, \mathrm{c}, \mathrm{d}}$ & $0.17 \pm 0.02^{b, c, d}$ & $346.0 \pm 57$ & $379.4 \pm 80^{b, c, d}$ \\
\hline 3-NPA & $3.88 \pm 0.88$ & $11.95 \pm 2.2$ & $4.75 \pm 1.0^{\mathrm{b}, \mathrm{c}, \mathrm{d}}$ & $0.15 \pm 0.10^{b, c, d}$ & $296.9 \pm 80$ & $166.8 \pm 46^{\mathrm{b}, \mathrm{c}, \mathrm{d}}$ \\
\hline
\end{tabular}

For symbols see Table II.

Applied doses: cerebrolysin $\left(2.5 \mathrm{~g} \mathrm{~kg}^{-1}\right), 3$-nitropropionic acid $\left(20 \mathrm{mg} \mathrm{kg}^{-1}\right)$. Mean value $\pm \mathrm{SD}, n=6$.

${ }^{a}$ Wet mass (tissue) basis.

$\mathrm{b}, \mathrm{c}, \mathrm{d}$ Statistically significant differences at $p<0.05$ within a parameter. 
D. C. Guzmán et al.: Effect of cerebrolysin on dopaminergic neurodegeneration of rat with oxidative stress induced by 3-nitropropionic acid, Acta Pharm. 66 (2016) 443-448.

Table IV. Dopamine levels and biomarkers of oxidative stress in cerebellum/medulla oblongata regions of young rats treated with cerebrolysin and 3-nitropropionic acid

\begin{tabular}{lcccccc}
\hline Group & $\begin{array}{c}\text { DA } \\
\left(\mu \mathrm{mol} \mathrm{g}^{-1}\right)^{\mathrm{a}}\end{array}$ & $\begin{array}{c}\text { TBARS } \\
(\mu \mathrm{mol} \\
\text { malondial- } \\
\text { dehyde g })^{-1}\end{array}$ & $\begin{array}{c}\text { Calcium } \\
(\mathrm{mg} \mathrm{per} \\
100 \mathrm{~mL})\end{array}$ & $\begin{array}{c}\mathrm{H}_{2} \mathrm{O}_{2} \\
\left(\mu \mathrm{mol} \mathrm{g}^{-1}\right)^{\mathrm{a}}\end{array}$ & $\begin{array}{c}\mathrm{GSH} \\
\left(\mathrm{nmol} \mathrm{g}^{-1}\right)^{\mathrm{a}}\end{array}$ & $\begin{array}{c}\text { ATPase } \\
(\mu \mathrm{mol} \mathrm{Pi} \\
\left.\mathrm{g}^{-1} \mathrm{~min}^{-1}\right)^{\mathrm{a}}\end{array}$ \\
\hline $\begin{array}{l}\text { Control } \\
\text { Cerebrolysin }\end{array}$ & $2.04 \pm 0.46^{\mathrm{b}}$ & $15.5 \pm 2.7$ & $4.26 \pm 0.10$ & $0.13 \pm 0.01$ & $221.0 \pm 73$ & $381.2 \pm 111$ \\
$\begin{array}{l}\text { Cerebrolysin } \\
\text { + 3-NPA }\end{array}$ & $2.31 \pm 0.55^{\mathrm{b}, \mathrm{c}}$ & $14.23 \pm 2.3$ & $4.22 \pm 0.09$ & $0.13 \pm 0.02$ & $191.0 \pm 55$ & $416.3 \pm 142$ \\
3-NPA & $3.40 \pm 1.87^{\mathrm{c}}$ & $13.64 \pm 2.1$ & $4.30 \pm 0.98$ & $0.12 \pm 0.01$ & $197.0 \pm 66$ & $401.7 \pm 48.3$ \\
\hline
\end{tabular}

For symbols see Table II.

Applied doses: cerebrolysin $\left(2.5 \mathrm{~g} \mathrm{~kg}^{-1}\right), 3$-nitropropionic acid $\left(20 \mathrm{mg} \mathrm{kg}^{-1}\right)$.

Mean value \pm SD, $n=6$.

${ }^{a}$ Wet mass (tissue) basis.

b,c Statistically significant differences at $p<0.05$ within DA values.

brolysin coincides with the findings of Patocková et al. (13). Besides, the increase of dopamine in the same groups suggests that DA may play a significant role in regulating the response to oxidative stress (14).

\section{CONCLUSIONS}

The increased dopamine metabolism due to the administration of cerebrolysin led to increased formation of radical species and oxidative stress, especially when free radicals were generated by 3-NPA. However, we recommend further studies to be conducted to investigate the possible beneficial effect of cerebrolysin on dopamine levels in other animal models.

Acknowledgements. - We thank Dr Cyril Ndidi Nwoye, a native English speaker and renowned, professional translator, for working on the translation and correction of the manuscript. The manuscript was edited by Taylor \& Francis Editing Services.

\section{REFERENCES}

1. A. Rami, D. Ferger and J. Krieglstein, Blockade of calpain proteolytic activity rescues neurons from glutamate excitotoxicity, Neurosci. Res. 27 (1997) 93-97.

2. A. Szabó, A. Papp and L. Nagymajtényi, Effects of 3-nitropropionic acid in rats: general toxicity and functional neurotoxicity, Arh. Hig. Rada Toksikol. 56 (2005) 297-302.

3. M. Hartbauer, B. Hutter-Paie and G. Skofitsch, Antiapoptotic effects of the peptidergic drug cerebrolysin on primary cultures of embryonic chick cortical neurons, J. Neural Transm. 108 (2001) 459-473.

4. G. D. Calderón, B. N. Osnaya, A. R. García, G. E. Hernández, M. G. Barragá and O. H. Juárez, Cerebrolysin and morphine decrease glutathione and 5-hydroxyindole acetic acid levels in fasted rat brain, Biomed. Pharmacother. 63 (2009) 517-521. 
5. J. M. Gutteridge and B. Halliwell, The measurement and mechanism of lipid peroxidation in biological systems, Trends Biochem. Sci. 5 (1990) 129-135.

6. J. Rem, O. Siggaard-Andersen, B. Nørgaard-Pedersen and S. Sørensen, Hemoglobin pigments. Photometer for oxygen saturation, carboxyhemoglobin, and methemoglobin in capillary blood, Clin. Chim. Acta 42 (1972) 101-108.

7. G. D. Calderón, B. N. Osnaya, A. R. García, G. E. Hernández and P. A. Guillé, Levels of glutathione and some biogenic amines in the human brain putamen after traumatic death, Proc. West. Pharmacol. Soc. 51 (2008) 27-29.

8. P. J. Hissin and R. Hilf, A fluorometric method for determination of oxidized and reduced glutathione in tissue, Anal. Biochem. 4 (1974) 214-226.

9. D. Calderón-Guzmán, I. Espitia-Vázquez, A. López-Domínguez, E. Hernández-García, B. HuertaGertrudis, E. Coballase-Urritia, H. Juárez-Olguín and B. Garcia-Fernández, Effect of toluene and nutritional status on serotonin, lipid peroxidation levels and $\mathrm{Na}^{+} / \mathrm{K}^{+}$ATPase in adult rat brain, Neurochem. Res. 30 (2005) 619-624.

10. K. S. Asru, Colorimetric assay of catalase, Anal. Biochem. 47 (1972) 389-394.

11. B. S. Mandavilli, I. Boldogh and B. van Houten, 3-Nitropropionic acid-induced hydrogen peroxide, mitochondrial DNA damage, and cell death are attenuated by Bcl-2 overexpression in PC12 cells, Brain Res. Mol. Brain Res. 133 (2005) 215-223.

12. C. L. German, M. G. Baladi, L. M. McFadden, G. R. Hanson and A. E. Fleckenstein, Regulation of the dopamine and vesicular monoamine transporters: Pharmacological targets and implications for disease, Pharmacol. Rev. 67 (2015) 1005-1024; DOI: 10.1124/pr.114.010397.

13. L. Patocková, M. Krsiak, P. Marhol and E. Tůmová, Cerebrolysin inhibits lipid peroxidation induced by insulin hypoglycemia in the brain and heart of mice, Physiol. Res. 52 (2003) 455-460.

14. M. E. Hanna, A. Bednářová, K. Rakshit, A. Chaudhuri, J. M. O’Donnell and N. Krishnan, Perturbations in dopamine synthesis lead to discrete physiological effects and impact oxidative stress response in Drosophila, J. Insect. Physiol. 73 (2015) 11-19; DOI: 10.1016/j.jinsphys.2015.01.001. 